\title{
SUPERCONDUCTING MATERIALS
}

Advances in

Technology and Applications 
This page is intentionally left blank 


\title{
International Advanced School \\ Leonardo Da Vinci
}

\section{SUPERCONDUCTING MATERIALS Advances in Technology and Applications}

1998 Summer Course, Bologna-Italy

\author{
Director of the Course \\ K. Kitazawa \\ Editors \\ A. Tampieri \& G. Celotti \\ IRTEC-CNR, Italy
}




\section{Published by}

World Scientific Publishing Co. Pte. Ltd.

P O Box 128, Farrer Road, Singapore 912805

USA office: Suite 1B, 1060 Main Street, River Edge, NJ 07661

UK office: 57 Shelton Street, Covent Garden, London WC2H 9HE

\section{British Library Cataloguing-in-Publication Data}

A catalogue record for this book is available from the British Library.

\section{SUPERCONDUCTING MATERIALS: ADVANCES IN TECHNOLOGY AND APPLICATIONS}

Copyright $(1) 2000$ by World Scientific Publishing Co. Pte. Ltd.

All rights reserved. This book, or parts thereof, may not be reproduced in any form or by any means, electronic or mechanical, including photocopying, recording or any information storage and retrieval system now known or to be invented, without written permission from the Publisher.

For photocopying of material in this volume, please pay a copying fee through the Copyright Clearance Center, Inc., 222 Rosewood Drive, Danvers, MA 01923, USA. In this case permission to photocopy is not required from the publisher.

ISBN 981-02-4295-6

Printed in Singapore by Uto-Print 


\title{
INTERNATIONAL ADVANCED SCHOOL Leonardo Da Vinci
}

For a continuing education programme

School Director W. Dusi

\section{Summer course 1998 \\ "Superconducting Materials: advances in}

\section{technology and applications"}

\author{
Course Director \\ K. Kitazawa
}

\author{
Scientific Coordinator \\ A. Tampieri
}

\begin{abstract}
Organized by
National Research Council, Research Institute for Ceramics Technology, Faenza National Research Council, Scientific Research Area, Bologna
\end{abstract}

\section{International Steering Committee}

E. V. Antipov Moscow State Univ. Russia, M. Ausloos Univ. of Liege Belgium, A. Barone Univ. of Naples Italy, B. Batlogg Lucent Tec. Bell Labs. USA, A. Campbell IRCS Cambridge UK, R. Cantelli Univ. "La Sapienza" Rome Italy, C. W. Chu Univ. of Texas, Houston USA D. Dew-Hughes University of Oxford UK, P.P. Edwards Univ. of Birmingham UK, R. Flukiger Univ. of Geneva Switzerland, R. Garré Europa Metalli, Fornaci di Barga Italy, K.C. Goretta Argonne Nation Lab. Argonne USA, L.P.Gor'kov National Magnetic Lab. USA, P.H. Kes Univ. of Leiden, The Netherlands, K. Kitazawa Tokyo University Japan, P. Komarek Univ. of Karlsruhe Germany, D.C. Larbalestier Univ. of Wisconsin Madison USA, M. Marezio MASPECCNR Parma Italy, M. Murakami ISTEC Tokyo Japan, N. Murayama NIRIN Nagoya Japan, F. Negrini Univ. of Bologna Italy, X. Obradors Univ. of Barcelona Spain, M. Rahman Pirelli Cavi Milan Italy, B. Raveau crismat-cnrs Caen France, C. Rizzuto Univ. of Geneva Italy, S. Zannella CISE Milan Italy, A.A. Zhukov Moscow State University Russia 
This page is intentionally left blank 
Felix qui potuit rerum cognoscere causas

(Virgilius, Geor. 2,490) 
This page is intentionally left blank 


\title{
Preface
}

These proceedings are a collection of the major part of the lectures held in the frame of the second course of the International Summer School "Leonardo da Vinci" on "Superconducting materials: advances in technology and applications".

Aim of this course was to present the state of the art and trends and new perspectives in the field of superconducting materials, related technologies and applications.

Attention was focused both on HTC and LTC superconductors, Fundamental aspects and theory, advances in material synthesis, processing and properties were featured as well as current developments in superconducting components and devices.

Since the teachers of the course are the most renowned international researchers in the field of superconductivity under the skilful guide of Prof. K. Kitazawa, we think that these Proceedings will represent a helpful tool for students' new generation.

\author{
A. Tampieri \\ G. Celotti \\ Faenza \\ July $15^{\text {th }}, 1999$
}


This page is intentionally left blank 


\section{Contents}

Preface

Introduction

Superconducting Materials: History and the Future

K. Kitazawa

Mechanism and Physical Properties of High Temperature

Superconductors

Critical Temperature

V. Z. Kresin

Magnetic Scattering

V. Z. Kresin

Critical Currents in Superconductors

M. Murakami

Superconducting Fluctuations and Their Role in the Normal State

Anomalies of High Temperature Superconductors

A. A. Varlamov

Pinning Mechanism in High- $T_{\mathrm{c}}$ and Conventional Superconductors

P. H. Kes, R. J. Drost, H. W. Zandbergen and A. A. Menovsky

Transport Properties of $H T_{c} \mathrm{~S}$ in a Temperature Gradient and a

B. Magnetic Field

M. Ausloos

More or Less Equilibrium: Properties in the so-called Normal State of High- $T_{\mathbf{c}}$ Superconductors

M. Ausloos 
Observation of Superconducting Vortices Using Advanced Electron Microscopy Techniques

M. Beleggia, R. Patti and G. Pozzi

The Role of Crystallography in the Understanding of High- $T_{\mathrm{c}}$

Superconductors: The Contribution of Electron Microscopy

C. Bougerol-Chaillout

High $T_{\mathrm{c}}$ Material Processing and Characteristics

159

Hg-Based Superconducting Cu Mixed Oxides

E. V. Antipov

Superconducting Properties of Melt Processed LRE-Ba-Cu-O

M. Murakami

Innovative Techniques in Superconducting Powders Synthesis and

Their Influence on Material Processing

A. Tampieri and G. Celotti

Ceramic Processing in High- $T_{\mathrm{c}}$ Superconductors

N. Murayama

Diffusion and Heat Treatment of High-Temperature Superconductors

K. C. Goretta and N. Chen

Weak Link Properties in Polycrystalline High- $T_{\mathrm{c}}$ Superconductors

N. Murayama

Mechanical Properties of Bulk High-Temperature Superconductors

K. C. Goretta

High Temperature Superconductor Thin Films: Deposition Techniques and in situ Characterizations 
Applications of Bulk High Temperature Superconductors

M. Murakami

Cryogenic Detectors Based on Superconducting Tunnel Junctions

E. Esposito

Microwave Surface Resistance Measurements in High- $T_{\mathrm{c}}$

Superconductors in a Magnetic Field

E. Silva

Microwave Applications of Thallium-Based High Temperature

Superconducting Thin Films

D. Dew-Hughes

Power Applications of High Temperature Superconductors

S. Zannella

New Techniques and Results in HTS for Power Applications

L. Martini

Low- $J_{\mathrm{c}}$ Applications of High- $T_{\mathrm{c}}$ Superconductors

F. Pavese, M. Bianco, M. Itoh, D. Giraudi and K. Mori 